\title{
lodine-131 treatment of thyroid cancer cells leads to suppression of cell proliferation followed by induction of cell apoptosis and cell cycle arrest by regulation of B-cell translocation gene 2-mediated JNK/NF-kB pathways
}

\author{
L.M. Zhao ${ }^{1}$ and A.X. Pang \\ ${ }^{1}$ Department of Nuclear Medicine, Linyi People's Hospital, Linyi, China \\ ${ }^{2}$ Department of Urology, Linyi People's Hospital, Linyi, China
}

\begin{abstract}
lodine-131 $\left({ }^{131} \mathrm{I}\right)$ is widely used for the treatment of thyroid-related diseases. This study aimed to investigate the expression of p53 and BTG2 genes following ${ }^{131}$ I therapy in thyroid cancer cell line SW579 and the possible underlying mechanism. SW579 human thyroid squamous carcinoma cells were cultured and treated with ${ }^{131} \mathrm{I}$. They were then assessed for ${ }^{131} \mathrm{I}$ uptake, cell viability, apoptosis, cell cycle arrest, p53 expression, and BTG2 gene expression. SW579 cells were transfected with BTG2 siRNA, p53 siRNA and siNC and were then examined for the same aforementioned parameters. When treated with a JNK inhibitor of SP600125 and ${ }^{131} \mathrm{I}$ or with a NF- $\mathrm{KB}$ inhibitor of BMS-345541 and ${ }^{131} \mathrm{I}$, non-transfected SW579 cells were assessed in JNK/NFKB pathways. It was observed that ${ }^{131} \mathrm{I}$ significantly inhibited cell proliferation, promoted cell apoptosis and cell cycle arrest. Both BTG2 and p53 expression were enhanced in a dose-dependent manner. An increase in cell viability by up-regulation in $B c / 2$ gene, a decrease in apoptosis by enhanced $C D K 2$ gene expression and a decrease in cell cycle arrest at $G_{0} / G_{1}$ phase were also observed in SW579 cell lines transfected with silenced BTG2 gene. When treated with SP600125 and ${ }^{131}$ I, the nontransfected SW579 cell lines significantly inhibited JNK pathway, NF-kB pathway and the expression of BTG2. However, when treated with BMS-345541 and ${ }^{131} \mathrm{I}$, only the NF-KB pathway was suppressed. ${ }^{131} \mathrm{I}$ suppressed cell proliferation, induced cell apoptosis, and promoted cell cycle arrest of thyroid cancer cells by up-regulating B-cell translocation gene 2-mediated activation of JNK/NF-кB pathways.
\end{abstract}

Key words: lodine-131; P53; BTG2; SW579; Thyroid cancer; JNK/NF-кB pathways

\section{Introduction}

The history of radionuclide therapy for the treatment of various diseases dates back to early 1900's. A parameter considered while choosing a particular radionuclide for therapy is the effective half-life, which is the net half-life considering both physical and biological half-life within the patient's body or organs. The biological half-life of a radionuclide depends on parameters like radiotracer delivery, uptake, metabolism, clearance, and excretion within the patient's body. The ionizing radiation leads to DNA damage, which is primarily caused by both direct or indirect interaction of radiation leading to molecular damage such as single strand break, double-strand breaks, base damage and DNA-protein cross links (1-4). It is established that cancer cells are more prone to damage following exposure to ionizing radiation than normal cells, which leads to the death of cancerous cells (5). The most widely used therapeutic radionuclide for the treatment of thyroid-related diseases such as differentiated thyroid cancer, Grave's disease, solitary hyper-functioning nodule, and toxic multinodular goiter is iodine-131 $\left({ }^{131} \mathrm{I}\right) .{ }^{131} \mathrm{I}$, an isotope of ${ }^{127} \mathrm{I}$, is commonly used as a beta emitter in radiation therapy, causing mutation and cell death. It is known that $10 \%$ of the energy and radiation dose is via gamma radiation. In a study by Eriksson et al. (6), radio-immunotherapy triggered apoptosis in tumor cells.

Expression of p53 at post-translational level is enhanced due to DNA damage by radiation (7), subsequently leading to the arrest of cell growth at G1 and/or G2 phase,

Correspondence: L.M. Zhao: <zhaoliming515@126.com> 
DNA repair, senescence or apoptosis (7-10). B-cell translocation gene 2 (BTG2) acts as a tumor suppressor gene for a number of cancers and it is stimulated by a p53dependent pathway, which subsequently leads to the DNA damage. BTG2 gene belongs to an anti-proliferative family protein which has highly conserved domains of BTG-Box A (Y50-N71) and BTG-Box B (L97-E115) (11-14). It has been reported that amongst the numerous molecules that are involved in diverse anti- or pro-apoptotic signaling pathways, NF-kB is one of the key factors controlling antiapoptotic responses. The anti-apoptotic effect is thought to be mediated through not only transcriptional activation of dependent genes but also by cross talking with the JNK pathway (15). In the present study, we have assessed the effects of ${ }^{131}$ I in thyroid cancer cell line SW579 with special emphasis on cell proliferation, apoptosis, and cell cycle arrest, and also explored the possible underlying mechanisms in JNK/NF-kB pathways.

\section{Material and Methods}

\section{Cell culture}

SW579 human thyroid squamous cell carcinoma cells were obtained from American Type Culture Collection (USA), and cultured in L-15 medium (GE Healthcare Life Sciences, USA) supplemented with $10 \%$ fetal calf serum (Gibco, USA), 2 mM glutamine (Gibco), penicillin (100 U/mL; SigmaAldrich, USA) and streptomycin (100 $\mu \mathrm{g} / \mathrm{mL}$; Amresco, USA), and maintained at $37^{\circ} \mathrm{C}$ without $\mathrm{CO}_{2}$ in a humidified atmosphere. SP600125 $(10 \mu \mathrm{M})$ and BMS-345541 $(10 \mu \mathrm{M})$ were used as JNK and NF- $\mathrm{KB}$ inhibitors to treat SW579 for 3 days, respectively (16).

\section{${ }^{131}$ I uptake assay}

The cells were seeded at $1 \times 10^{5} /$ well on 6 -well plates for $24 \mathrm{~h}$. Subsequently, the cells were cultured for $24 \mathrm{~h}$ with $2 \mathrm{~mL}$ culture medium per well containing 7.4, 14.8, $29.4 \mathrm{MBq} / \mathrm{mL}^{131} \mathrm{I}(9)$.

\section{CCK-8 assay}

SW579 cells were seeded on 96-well plate with 5000 cells/well, and cell proliferation was assessed by the Cell Counting Kit-8 (CCK-8, Dojindo Molecular Technologies, USA). Briefly, after stimulation, the CCK-8 solution was added to the culture medium, and the cultures were incubated for $1 \mathrm{~h}$ at $37^{\circ} \mathrm{C}$ in humidified $95 \%$ air and $5 \%$ $\mathrm{CO}_{2}$. The absorbance was measured at $450 \mathrm{~nm}$ using a Microplate Reader (Bio-Rad, USA).

\section{Apoptosis assay \\ Cell apoptosis analysis was performed using propi- dium iodide (PI) and fluorescein isothiocynate (FITC)- conjugated Annexin $\mathrm{V}$ staining. Briefly, cells were washed in phosphate-buffered saline (PBS) and fixed in $70 \%$ ethanol. Fixed cells were then washed twice in PBS and stained in PI/FITC-Annexin $V$ in the presence of $50 \mu \mathrm{g} / \mathrm{mL}$}

RNase A (Sigma-Aldrich), and then incubated for $1 \mathrm{~h}$ at room temperature in the dark. Flow cytometry analysis was done by using a FACScan (Beckman Coulter, USA). Data were analyzed with FlowJo software.

\section{Cell cycle assay}

For analysis of cell cycle, cells with different treatments were trypsinized, washed twice in PBS, and fixed overnight at $-20^{\circ} \mathrm{C}$ in $300 \mu \mathrm{L}$ PBS and $700 \mu \mathrm{L}$ ethanol. The fixed cells were spun down gently in $200 \mu \mathrm{L}$ extraction buffer $\left(0.1 \%\right.$ Triton $\mathrm{X}-100,45 \mathrm{mM} \mathrm{Na}_{2} \mathrm{HPO}_{4}$ and $2.5 \mathrm{mM}$ sodium citrate) at $37^{\circ} \mathrm{C}$ for $20 \mathrm{~min}$ and then stained with $\mathrm{PI}$ (BD Biosciences, USA) $(50 \mu \mathrm{g} / \mathrm{mL})$ containing $50 \mu \mathrm{g} / \mathrm{mL}$ RNase $A$ for 30 min at $37^{\circ} \mathrm{C}$ in the dark, and subsequently analyzed by FACScan. The experiment was repeated at least three times, and the data were analyzed using CellQuest and ModFit softwares (Verity Software House, USA).

\section{qRT-PCR}

Total RNA was extracted with TRIzol reagent according to the manufacturer's protocol (Sigma) and $2 \mu \mathrm{g}$ were reverse-transcribed with the Omniscript RT kit (Qiagen, Italy) using random primers $(1 \mathrm{mM})$ at $37^{\circ} \mathrm{C}$ for $1 \mathrm{~h}$. Real time PCR was performed in triplicate in $20 \mathrm{~mL}$ reaction volumes using the Power SYBER Green PCR Master Mix (Applied Biosystems, USA). All primers were purchased from Invitrogen Life Technologies (USA). Real time PCR reactions were carried out in a MJ MiniTM Personal Thermal Cycler apparatus (Bio-Rad Laboratories, USA). Melting curves were obtained by increasing the temperature from 60 to $95^{\circ} \mathrm{C}$ with a temperature transition rate of $0.5^{\circ} \mathrm{C} / \mathrm{s}$. The comparative threshold cycle number (CT) method was used to assess the relative quantification of gene expression. The fold change of the target gene was calculated as $2^{-\Delta \Delta C T}$.

\section{siRNAs transfection}

BTG2 siRNA, p53 siRNA, and siNC were designed and synthesized by GenePharma (China). Cell transfection was performed using Lipofectamine 3000 (Invitrogen Life Technologies) according to the manufacturer's instructions.

\section{Statistical analysis}

All experiments were repeated three times. The results of multiple experiments are reported as means \pm SD. Statistical analyses were performed using SPSS 19.0 statistical software. Differences were compared using a one-way analysis of variance (ANOVA). A P-value of $<0.05$ was considered to be statistically significant.

\section{Results}

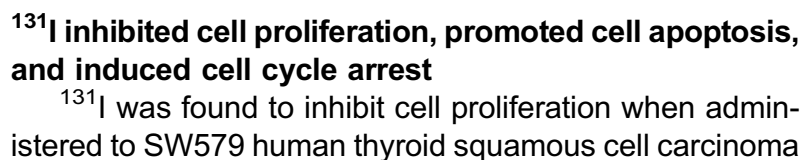



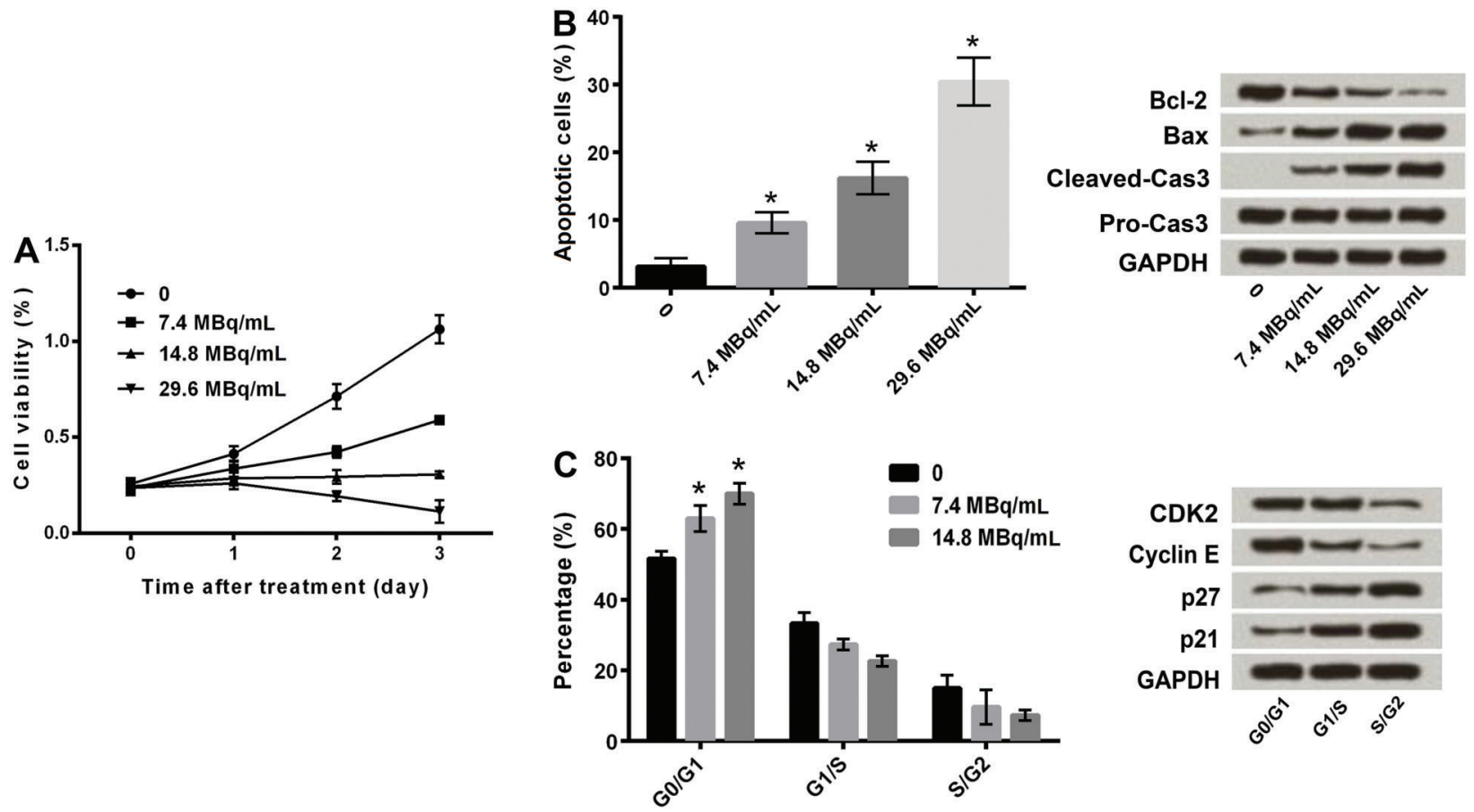

Figure 1. Effects of iodine-131 $\left({ }^{131} \mathrm{I}\right)$ on cell proliferation $(A)$, cell apoptosis $(B)$ by regulating apoptosis-related protein, and cell cycle arrest $(C)$ by modulating cell cycle-related protein. Data are reported as means $\pm S D$. ${ }^{*} P<0.05$ compared with control $(C T L-G A P D H)$ (ANOVA).

cell lines. Cell viability was lesser than $0.5 \%$ at 14.8 $(\mathrm{P}<0.05)$ and $29.4 \mathrm{MBq} / \mathrm{mL}$ (significantly lower than cell viability at $7.4 \mathrm{MBq} / \mathrm{mL}$; Figure $1 \mathrm{~A})$. A significant increase in apoptosis was observed when SW579 cells was treated with ${ }^{131} \mathrm{I}$ at 29.6 and $14.8 \mathrm{MBq} / \mathrm{mL}(\mathrm{P}<0.05$; Figure $1 \mathrm{~B})$. Furthermore, expression of $\mathrm{Bcl}-2$ was suppressed by 0.5 fold, and Bax and cleaved-Cas 3 genes were enhanced by 1.5 and 1.5 folds, respectively, at $14.8 \mathrm{MBq} / \mathrm{mL}$ compared to GAPDH expression used as endogenous control.

${ }^{131} \mathrm{I}$ induced cell cycle arrest significantly by more than $60 \%$ at $\mathrm{G}_{\mathrm{o}} / \mathrm{G}_{1}$ at the concentration of $14.8 \mathrm{MBq} / \mathrm{mL} \mathrm{com}-$ pared to the arrest at $G_{1} / S$ and $S / G_{2}$, by suppressing the expression of cyclin-dependent kinases 2 (CDK2) and cyclin $\mathrm{E}$ by 0.5 and 0.4 folds, respectively, at $14.8 \mathrm{MBq} / \mathrm{mL}$ compared to GAPDH expression $(\mathrm{P}<0.05)$. Furthermore, the expressions of $p 27$ and $p 21$ genes were enhanced by 1.5 and 2 folds, respectively, at $14.8 \mathrm{MBq} / \mathrm{mL}$ compared to GAPDH expression (Figure 1C).

\section{${ }^{131} \mathrm{I}$ induced the expressions of p53 and BTG2}

As shown in Figure 2A, ${ }^{131} \mathrm{I}$ increased the expressions of $\mathrm{p} 53$ and BTG2 in a concentration-depended manner. The expression of BTG2 was raised even after silencing of p53, thereby indicating that the higher expression of BTG2 was only partly dependent on p53 expression $(P<0.05)$ (Figure 2B).
Silencing of BTG2 reversed the effects of ${ }^{131}$ I on cell proliferation, cell apoptosis, and cell cycle arrest

SW579 cells transfected with silenced BTG2 gene (Figure $3 \mathrm{~A}$ ) and treated with ${ }^{131} \mathrm{I}$, presented an increase in cell viability (more than $0.5 \%$ ) at $14.8 \mathrm{MBq} / \mathrm{mL}$ (Figure $3 \mathrm{~B}$ ), unlike in non-transfected cells, shown in Figure 1. Similarly, a significant decrease in apoptosis (approximately 10\%) was found in cells transfected with silenced BTG2 gene compared to non-transfected cells, where apoptosis was approximately $20 \%$, when treated with ${ }^{131}$ I (Figure $3 \mathrm{C}$ ). A down-regulation in $\mathrm{Bcl} 2$ and an up-regulation in Bax by 2.0 and 1.2 folds, respectively, were observed in cell proliferation pathway. A significant decrease in cell cycle arrest (less than $60 \%$ ) was also observed at $\mathrm{G}_{\mathrm{o}} / \mathrm{G}_{1}$ stage in cells transfected with silenced BTG2 gene compared to non-transfected cells. Assessment of the molecular pathway revealed that there was an up-regulation in CDK2, followed by down-regulation in cyclin $E$ and $p 27$ genes and down-regulation in $p 21$ gene (Figure 3D).

\section{${ }^{131}$ I up-regulated BTG2 expression by activation of JNK/NF- $\mathrm{B}$ p pathways}

As shown in Figure 4, non-transfected SW579 cells treated with SP600125, a JNK inhibitor, and ${ }^{131} \mathrm{I}$ at $14.8 \mathrm{MBq} /$ $\mathrm{mL}$ not only had a significant inhibition of JNK pathway

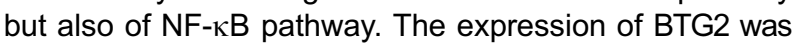



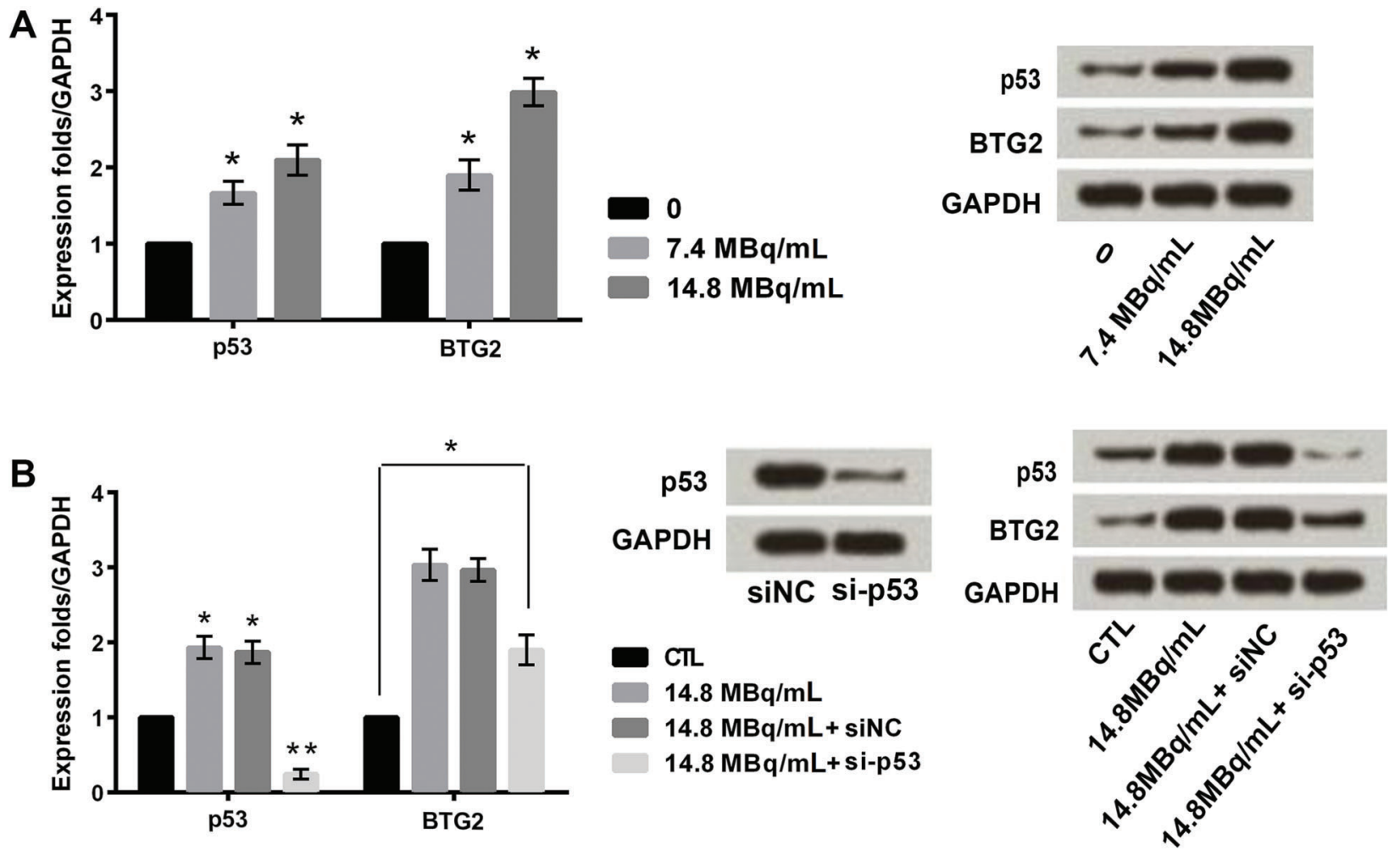

Figure 2. Effects of different concentrations of iodine-131 $\left({ }^{131} \mathrm{I}\right)$ on expression of p53 and BTG2 $(A)$. B, Expression of BTG2 was raised even with silencing of $p 53$ (si-p53). Data are reported as means \pm SD. ${ }^{*} \mathrm{P}<0.05$. ${ }^{* *} \mathrm{P}<0.01$ compared with control (CTL - GAPDH) (ANOVA).

also down-regulated. Furthermore, non-transfected SW579 cells treated with BMS-345541, a NF- $\mathrm{BB}$ inhibitor, and ${ }^{131} \mathrm{I}$ at $14.8 \mathrm{MBq} / \mathrm{mL}$ had only the expression of $\mathrm{NF}-\kappa \mathrm{B}$ pathway affected but not of the JNK pathway. The expression of BTG2 was down-regulated, thus indicating that ${ }^{131}$ I up-regulated BTG2 expression by activation of JNK/NF-KB pathways.

\section{Discussion}

It is well known that ${ }^{131}$ I destroys residual thyroid cancer tissue after surgical resection of differentiated thyroid carcinoma. The degree to which DNA is damaged by ionizing radiation depends on factors like type and dose of radiation $(17,18)$. In the present study, we evaluated the role of ${ }^{131} \mathrm{I}$ in cell proliferation, apoptosis and cell cycle arrest in a thyroid cancer cell line, together with the exploration of the possible underlying mechanism (increased expression of BTG2 gene-mediated activation of the JNK/NF-KB pathways). ${ }^{131}$ I significantly inhibited cell proliferation as assessed in terms of cell-viability, enhanced cell apoptosis by down-regulating $\mathrm{Bc} / 2$ gene, and promoted cell cycle arrest at $\mathrm{G}_{0} / \mathrm{G}_{1}$ phase by down-regulating $C D K 2$ gene. Cell apoptosis is largely regulated by protein-protein interactions between members of the $\mathrm{Bcl}-2$ protein family. It is known that members of $\mathrm{Bcl}-2$ family genes have conserved domains called $\mathrm{Bcl}-2$ homology domains, which are differentially modulated in various cancers $(19,20)$.

Furthermore, ${ }^{131} \mathrm{I}$ increased both BTG2 and p53 expression in a dose-dependent manner. It is mportant to mention that ${ }^{131}$ I enhanced the expression of BTG2, after silencing p53 gene in SW579 cells, suggesting that the expression of BTG2 was partly dependent on the p53 gene. An increase in cell viability by up-regulation in $B c / 2$ gene, a decrease in apoptosis by enhanced CDK2 gene expression and a decrease in cell cycle arrest at $\mathrm{G}_{0} / \mathrm{G}_{1}$ phase were also observed in SW579 cells transfected with silenced BTG2 gene. Moreover, it was observed that not only the JNK pathway in the non-transfected SW579 cells, treated with SP600125, a JNK inhibitor, and ${ }^{131}$ I at 14.8 MBq/mL, was significantly inhibited but also the NF$\kappa \mathrm{B}$ pathway was inhibited along with the down-regulation of the BTG2 expression. Again, when treated with BMS345541, a NF-אB inhibitor, and ${ }^{131}$ I, SW579 cells revealed only suppression of the NF-kB pathway but not that of the JNK pathway. Considering the aforementioned effects of ${ }^{131}$ I, we can conclude that ${ }^{131}$ I up-regulated BTG2 expression by activation of JNK/NF-KB pathways. 
A
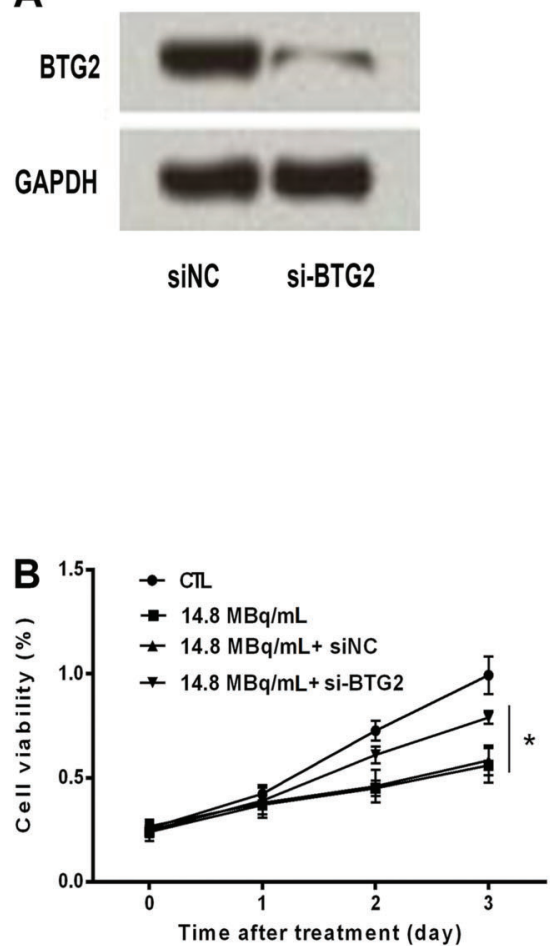

C

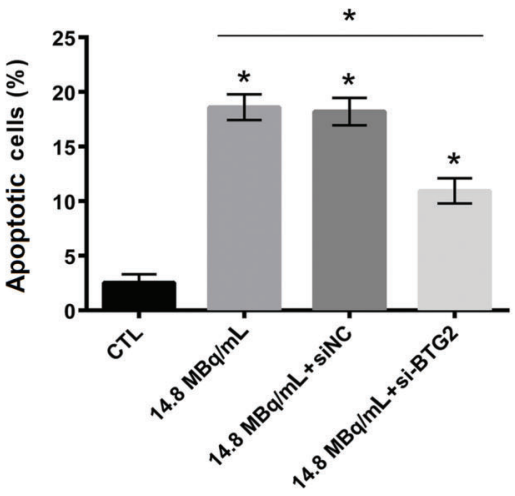

D

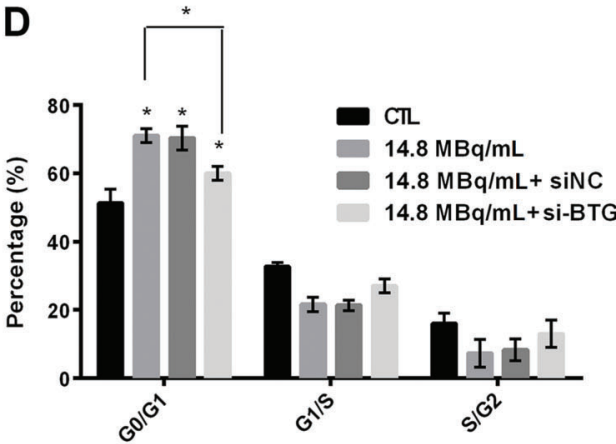

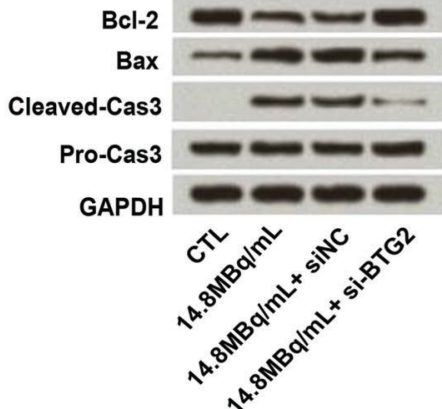

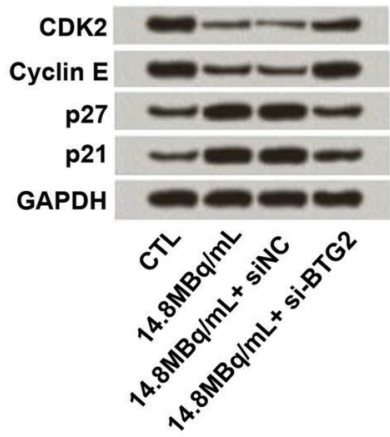

Figure 3. $A$, Transfection efficiency of BTG2. Silencing of BTG2 increased iodine-131 ( $\left.{ }^{131} \mathrm{I}\right)$-induced cell proliferation $(B)$, ${ }^{131} \mathrm{I}$-induced cell apoptosis $(C)$, and down-regulated ${ }^{131}$ l-induced cell cycle arrest $(D)$. Data are reported as means $\pm \mathrm{SD}$. ${ }^{*} \mathrm{P}<0.05$ compared with control (CTL - GAPDH) (ANOVA).

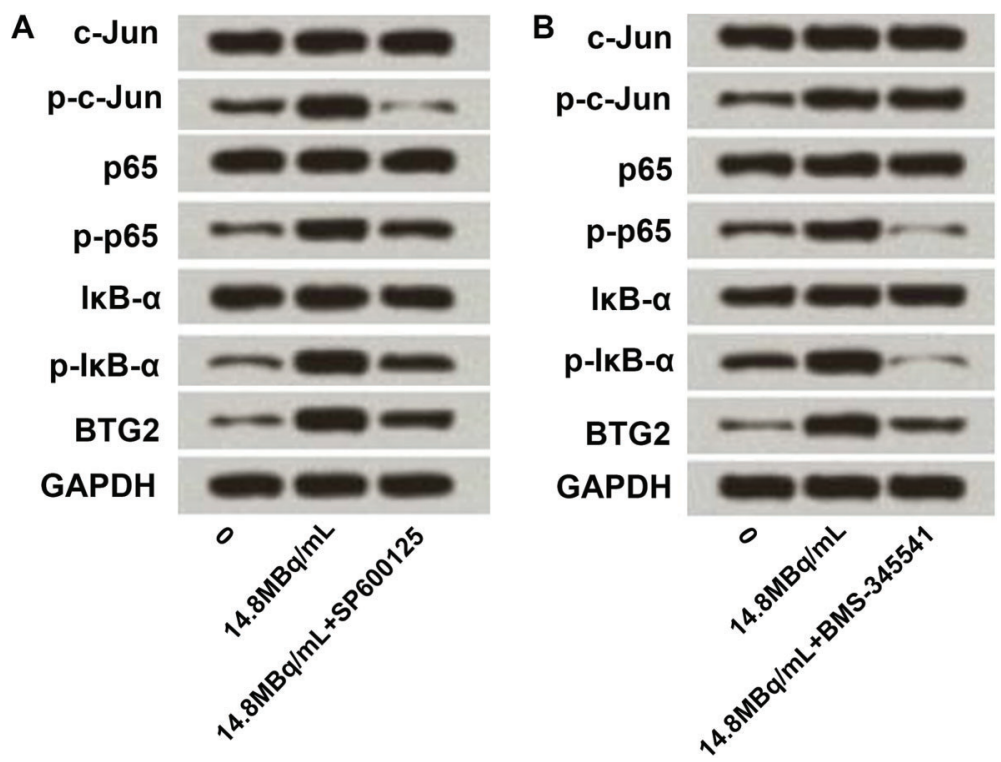

Figure 4. $A$ and $B$, lodine-131 up-regulated BTG2 expression by activation of JNK/NF-кB pathways. 


\section{References}

1. Oleinick NL, Chiu SM, Ramakrishnan N, Xue LY. The formation, identification, and significance of DNA-protein cross-links in mammalian cells. Br J Cancer Suppl 1987; 8: 135-140.

2. Nikjoo H, O'Neill P, Goodhead DT, Terrissol M. Computational modelling of low-energy electron-induced DNA damage by early physical and chemical events. Int J Radiat Biol 1997; 71: 467-483, doi: 10.1080/095530097143798.

3. van Gent DC, Hoeijmakers JH, Kanaar R. Chromosomal stability and the DNA double-stranded break connection. Nat Rev Genet 2001; 2: 196-206, doi: 10.1038/35056049.

4. Walters K. Modelling the probability distribution of the number of DNA double-strand breaks due to sporadic alkylation of nucleotide bases. J Theor Biol 2007; 245: 161-168, doi: 10.1016/j.jtbi.2006.09.028.

5. Neshasteh-Riz A, Koosha F, Mohsenifar A, Mahdavi SR. DNA Damage Induced in Glioblastoma Cells by I-131: A Comparison between Experimental Data and Monte Carlo Simulation. Cell J 2012; 14: 25-30.

6. Eriksson D, Blomberg J, Lindgren T, Lofroth PO, Johansson $\mathrm{L}$, Riklund K, et al. lodine-131 induces mitotic catastrophes and activates apoptotic pathways in HeLa Hep2 cells. Cancer Biother Radiopharm 2008; 23: 541-549, doi: 10.1089/cbr. 2008.0471.

7. Reinhardt HC, Schumacher B. The $\mathrm{p} 53$ network: cellular and systemic DNA damage responses in aging and cancer. Trends Genet 2012; 28: 128-136, doi: 10.1016/j.tig.2011. 12.002.

8. Jin S, Levine AJ. The p53 functional circuit. J Cell Sci 2001; 114: 4139-4140.

9. Feng $Z$, Levine AJ. The regulation of energy metabolism and the IGF-1/mTOR pathways by the p53 protein. Trends Cell Biol 2010; 20: 427-434, doi: 10.1016/j.tcb.2010. 03.004 .

10. Zhang W, Gao R, Yu Y, Guo K, Hou P, Yu M, et al. lodine131 induces apoptosis in HTori-3 human thyrocyte cell line and $\mathrm{G} 2 / \mathrm{M}$ phase arrest in a p53-independent pathway. Mol Med Rep 2015; 11: 3148-3154.

11. Chiang KC, Tsui KH, Chung LC, Yeh CN, Feng TH, Chen WT, et al. Cisplatin modulates B-cell translocation gene 2 to attenuate cell proliferation of prostate carcinoma cells in both p53-dependent and p53-independent pathways. Sci Rep 2014; 4: 5511, doi: 10.1038/srep05511.

12. Lim IK. TIS21 (/BTG2/PC3) as a link between ageing and cancer: cell cycle regulator and endogenous cell death molecule. J Cancer Res Clin Oncol 2006; 132: 417-426, doi: 10.1007/s00432-006-0080-1.

13. Cortes U, Moyret-Lalle C, Falette N, Duriez C, Ghissassi FE, Barnas C, et al. BTG gene expression in the p53-dependent and -independent cellular response to DNA damage. Mol Carcinog 2000; 27: 57-64, doi: 10.1002/(SICl)1098-2744 (200002)27:2<57::AID-MC1 > 3.0.CO;2-I.

14. Rouault JP, Falette N, Guehenneux F, Guillot C, Rimokh R, Wang $Q$, et al. Identification of BTG2, an antiproliferative p53-dependent component of the DNA damage cellular response pathway. Nat Genet 1996; 14: 482-486, doi: 10.1038/ng1296-482.

15. Namba H, Saenko V, Yamashita S. Nuclear factor-kB in thyroid carcinogenesis and progression: a novel therapeutic target for advanced thyroid cancer. Arq Bras Endocrinol Metabol 2007; 51: 843-851, doi: 10.1590/S0004-273020 07000500023.

16. Yu J, Ren P, Zhong T, Wang Y, Yan M, Xue B, et al. Pseudolaric acid B inhibits proliferation in SW579 human thyroid squamous cell carcinoma. Mol Med Rep 2015; 12: 7195-7202.

17. Reisz JA, Bansal N, Qian J, Zhao W, Furdui CM. Effects of ionizing radiation on biological molecules -mechanisms of damage and emerging methods of detection. Antioxid Redox Signal 2014; 21: 260-292, doi: 10.1089/ars.2013.5489.

18. Moore S, Stanley FK, Goodarzi AA. The repair of environmentally relevant DNA double strand breaks caused by high linear energy transfer irradiation - no simple task. DNA Repair 2014; 17: 64-73, doi: 10.1016/j.dnarep.2014.01.014.

19. Thomadaki $\mathrm{H}$, Scorilas A. BCL2 family of apoptosis-related genes: functions and clinical implications in cancer. Crit Rev Clin Lab Sci 2006; 43: 1-67, doi: 10.1080/1040836050 0295626.

20. van Delft MF, Huang DC. How the Bcl-2 family of proteins interact to regulate apoptosis. Cell Res 2006; 16: 203-213, doi: $10.1038 /$ sj.cr.7310028. 